\title{
Customization of product, service, and product/service system: what and how to design
}

\author{
Tatsunori HARA*, Tomohiko SAKAO** and Ryo FUKUSHIMA* \\ * Research into Artifacts, Center of Engineering (RACE), The University of Tokyo \\ 5-1-5 Kashiwanoha, Kashiwa, Chiba, 277-8568, Japan \\ E-mail: hara_tatsu@race.u-tokyo.ac.jp \\ ** Division of Environmental Technology and Management, Department of Management and Engineering, Linköping University \\ 58183 Linköping, Sweden
}

Received: 9 April 2018; Revised: 20 September 2018; Accepted: 28 October 2018

\begin{abstract}
Customizing offerings to match customers' specific needs is a common practice for manufacturers striving to maintain their competence in markets. Despite Product/Service Systems (PSSs) having developed substantially in industry and academia for the last two decades, no scientific review of PSS customization has been published. This prompted us to conduct a review of scientific papers relating to products, services, and PSS customization with a focus on design, with the aim of clarifying future research directions in PSS customization. In particular, distinct design models and methods were individually examined, with a special focus on service aspects, in terms of what to design and how to design it. The population of papers included in the review was those included in the Web of Science. Even though service customization has been utilizing the knowledge generated by product customization, which has been researched extensively for decades, there are differences between them, such as the difficulty associated with modularity. The same or even larger differences apply to PSS customization, because, apart from service characteristics, PSS also has product characteristics and thus is more complex. Results also include that the module-based platform strategy used in service customization can also be used for PSS. Although several papers concerned with PSS customization have been published thus far, their focus has been on the service aspect of PSS, providing further research opportunities. Existing methods to design PSS can be also applied to develop a method for PSS customization.
\end{abstract}

Keywords : Customization, Product/service system, PSS, Integrated solution, Design science, Platform, Literature review, Modularity

\section{Introduction}

Manufacturers aim to add value to their offerings in response to individual customer needs and wants, i.e., they customize their offerings ( $\mathrm{Hu}$ et al., 2011). In terms of product customization, the notion of mass customization and customized products with near mass production pricing has been practiced for over two decades (Anderson, 1997, Pine, 1997). A model for product family architecture and its associated methods has been developed in the field of product family design (e.g., Jiao et al. (2007)). Service customization models for software languages emerged (e.g., Moon et al. (2011)). As an additional trend in industry, the development of services in combination or integration with physical products became crucial for an increasingly large number of manufacturers to retain their competitiveness amidst fierce global competition (Meier et al., 2010, Baines et al., 2017). Concepts supporting the design of both products and services in an integrated manner were developed and supported in industry, such as the Product/Service System (PSS) (Tukker and Tischner, 2006). PSS is defined as tangible products and intangible services designed and combined to fulfill specific customer needs (Tischner et al., 2002). Providing PSS in industry indeed involves customization (Sakao et al., 2008). Further, PSS is expected to enhance the environmental performance of product lifecycles (Tukker, 2015), which increases the relevance of PSS research even more from the viewpoint of society. In the light of the definition of PSS, here a product is defined as a tangible, physical entity, whereas a service is defined as an intangible activity. 
When pursuing PSS customization, manufacturers face challenges. The main reason is that customizing an offering requires a manufacturer to investigate various possible alternatives (Hu et al., 2011) and integrating both products and services into one offering is complex (Song et al., 2015). Addressing these challenges offers high potential for scientific research for the following reasons. First, only a few models, methods, and tools have been proposed for the customization of PSS (e.g., Song and Sakao (2017)). Second, methods for PSS design that could be further developed for application to PSS customization are available (Vasantha et al., 2012). Third, different models, methods, and tools that have been proposed for the customization of either physical products (e.g., Fogliatto et al. (2012)) or services (e.g., Moon et al. (2009)) are also available for application to PSS customization. Nonetheless, no scientific review for PSS customization has been published to date to highlight future research directions in PSS customization. None of the existing reviews even cover both product and service customization.

Therefore, this article presents a literature review of product, service, and PSS customization. This review focuses on computer-aided design (CAD) support based on design science (Hubka and Eder, 1996) for PSS customization. CAD support is highly promising to address the inherent complexity of PSS customization as implied by several reviews of PSS in software engineering (Berkovich et al., 2011, Boehm and Thomas, 2013, Qu et al., 2016). Special attention is devoted to what can be learned from the customization of products and services, respectively, with respect to the customization of PSS. The article mainly aims to contribute to forthcoming research concerned with PSS customization, but also provides learning back to product and service customization. The remainder of this article is structured as follows. Section 2 explains the research methodology. Section 3 shows the results of our analysis of the relevant literature. Section 4 discusses the results including future research directions. Section 5 concludes this paper.

\section{Research Methodology}

This research builds upon different categories of existing research in terms of the design object (i.e., what to design) and design process (i.e., how to design it). Literature related to customization covering products, services, and PSS, was included. Because of the imbalance between the literature pertaining to products, services, and PSS, different approaches were applied. Considering the small amount of research that focused on service and PSS customization, the features proposed by each of the studies were examined and incorporated. On the other hand, taking into account the huge amount of research regarding product customization, only those features that were frequently found were incorporated to ensure the feasibility of this research. This way is more effective than examining each study even in product customization, which makes it difficult to include an overview of the three different areas in one review article. The detailed methodology is described below.

Phase 1. Literature review of PSS design: Literature addressing the conceptual design of PSS was reviewed. The aim was to select a model for designing the most promising PSS for examining models detected during the later phase. This phase consisted of three steps: 1) keyword search, 2) screening, and 3) comparison of the models. The population consisted of those publications written in English and incorporated in the Web of Science (WoS) databases in consideration of the impact factors of the journals. The conditions applied to 1) keyword search, were that the title should include "service," "PSS," (as a single phrase), "integrated solution," or "hybrid offering" and that the topic should include "CAD," whereas the research area should be either "engineering" or "computer science," and the document type should be "article". In 2) screening, the correspondence with the context of the article and the implementation in software were necessary conditions because of the focus on CAD support and design science as stated in Section 1. Furthermore, articles by the same authors were consolidated and a representative one was chosen. In 3) the comparison, the different models were evaluated mainly in terms of their potential.

Phase 2. Literature review of customization: A literature review based on a search for descriptions of the conceptual design of the customization of products, services, or PSS, was conducted. The aim was to capture those features that could be incorporated into the selected model mentioned in Phase 1. A concept matrix, an effective tool for a scientific review in general (Webster and Watson, 2002), was adopted, if applicable. The population was again those publications written in English and included in the WoS databases. For service or PSS customization, the review required a close investigation of individual, original research articles, whereas for product customization, the objective of the investigation was to primarily include review articles. If the product customization literature was not limited to review articles, the volume of available material would have made the composition of this article infeasible by destroying its unique contribution of including both product and service customization. 
Specifically, for service customization, four steps were applied; 1) keyword search, 2) screening, 3) comparison of the models, and 4) extracting features from the literature. The conditions for 1) keyword search were that the title should include "customization" or "service family design," the topic should include "service," the research area should be "engineering" and the document type should be "article." For 2) screening, only those articles providing a distinctive model or process with a design science perspective for the customization were chosen. For 3) the comparison of the models, a set of parameters obtained from the key concepts of the selected models was utilized.

For PSS customization, four steps were applied; 1) keyword search, 2) screening, 3) comparison of the models, and 4) extracting features from the literature. The conditions for 1) keyword search were that the title should include "customization," "PSS family design," "integrated solution family design," or "hybrid offering family design," the topic should include "product service system," "integrated solution," or "hybrid offering" and the document type should be "article." For 2) screening, only those articles providing a distinctive model or process taking a design science perspective for customization were chosen. For 3) the comparison of the models, a set of parameters obtained from the key concepts of the selected models was utilized.

For product customization, three steps were applied; 1) keyword search, 2) screening, and 3) extracting features from the literature. The conditions for 1) keyword search were that the title should include "customization" or "product family design," the topic should include "product," the research area should be "engineering", and the document type should be "review." In 2) screening, only those review articles providing a substantial review of the design science aspect of customization were selected.

\section{Results of Literature Review}

\subsection{Development of the areas}

Figure 1 shows the transition of the number of articles about PSS design, service customization, and PSS customization. Studies involving PSS design including software implementation appeared from 2003 onward. Especially in the last decade, PSS design seems to have attracted higher attention. Although distinct models of service customization have been proposed since the 1990s, most of them were proposed in the last decade. Development of distinct models of PSS customization has emerged since 2011. However, in the light of increased attention to service customization and PSS design over the years, PSS customization is logically believed to attract more attention as a research topic. This supported the need for a review providing future research directions for PSS customization.

7

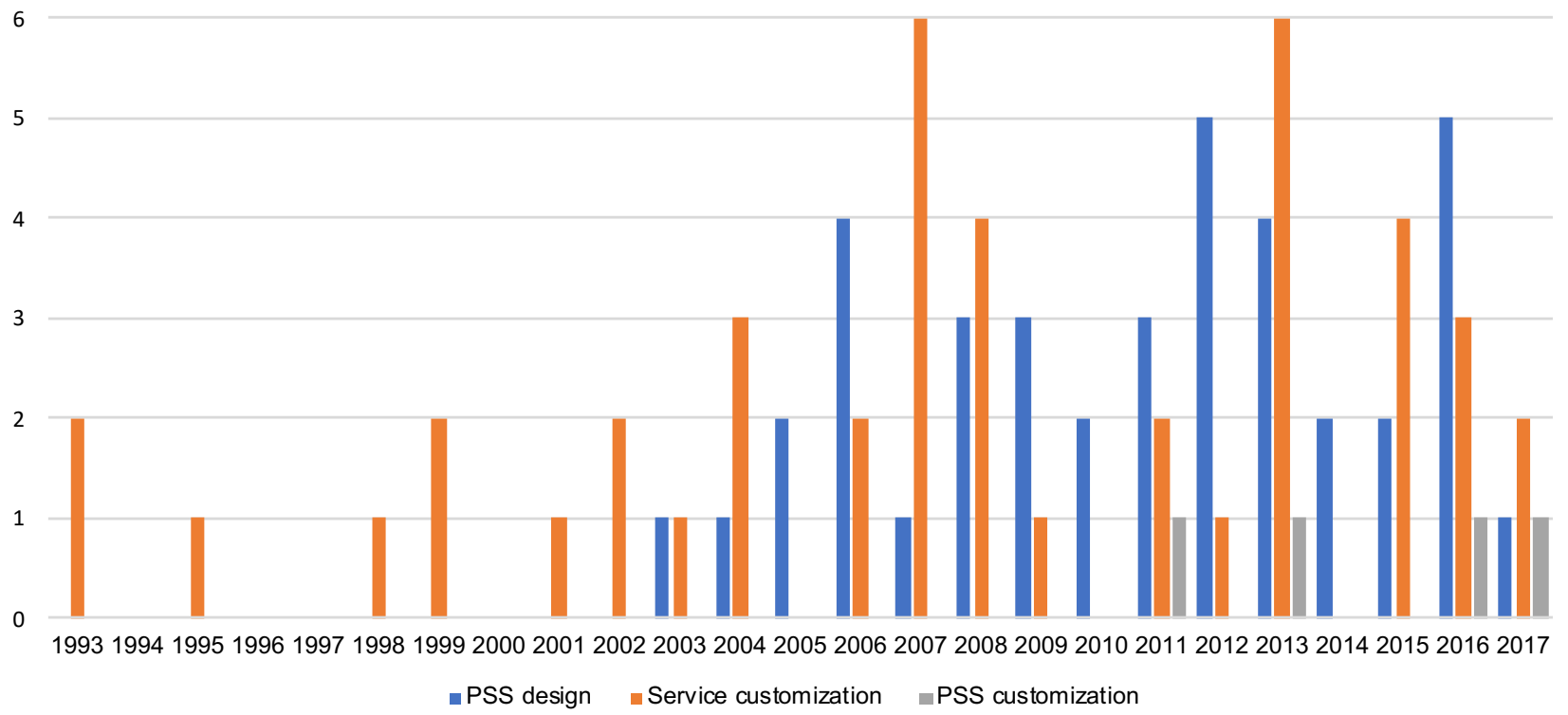

Figure 1. Transition of the number of articles relating to PSS design, service customization, and PSS customization 


\subsection{Literature in PSS design (Phase 1)}

The keyword search of the literature review for the design of PSS (as specified in Section 2) produced 40 articles as of March 24, 2018. As a general observation, several models, methods, and tools for the design and management of PSS have been proposed, as reviewed (Meier et al., 2010(Vasantha et al., 2012). For instance, "total care products" (functional products) (Alonso-Rasgado et al., 2004), which are combinations of hardware and support services, have been developed in the engineering domain. Recently, a comprehensive general PSS model has been proposed (Becker et al., 2010). Several methods for designing PSS have also been proposed. Most are formulated in a qualitative manner (Morelli, 2003, Aurich et al., 2006, Sakao and Shimomura, 2007), whereas a few others followed a quantitative approach (Geng et al., 2010, Geng and Chu, 2012). Service activity is increasingly incorporated into the design space across these concepts; this has traditionally been the domain of physical products in the manufacturing industries.

After screening, three articles that present distinctive models were obtained after the precondition of implementation in software eliminated most of the 40 articles. Namely, very few examples of software for the design of PSS were found even at the research level: a service CAD integrated with a lifecycle simulator (Komoto and Tomiyama, 2008), a service CAD named "Service Explorer" (Hara et al., 2009, Sakao et al., 2009, Shimomura and Hara, 2010, Akasaka et al., 2012), and PSS-CAD (McKay and Kundu, 2014). None of them addresses customization explicitly.

Using the concept of the Service Explorer as criteria, papers reporting service, PSS, and product customization are examined in terms of the design object (i.e., what to design) and the design process (i.e., how to design it). Design support systems are also examined. Two tables, one about the design object and the design support system and the other about the design process, are created for the review of each type of customization. The receiver state parameter (RSP) used in design objects is a unique concept in Service Explorer. The offerings affect customers and change the states of customers to new states. RSP represents this change of customer states (Arai and Shimomura, 2004).

\subsection{Literature in Customization (Phase 2) \\ 3.3.1 Service customization}

The keyword search for the literature review of service customization (as specified in Section 2) produced 44 articles as of March 24, 2018. After screening, four articles that present a distinctive model or process (as listed in Tables 1 and 2) from the design science perspective were obtained. Most articles were eliminated because of their low relevance to design science. Tables 1 and 2 are concept matrices that compare the models by using the elements of the model for designing PSS as selected in Section 3.1 - Table 1 for design objects and design support systems, and Table 2 for design processes. Tables 1 and 2 reveal that no single model addresses all the elements of the model for designing PSS.

Table 1 shows that all the elements such as the function, entity, and process are addressed by at least some of the models. Note that "product elements" are not major design parameters in most of these models. This is reasonable as these models are developed for service customization and all the case studies carried out as part of the related research involved the service industry (shown in the last line of Table 1, "Case used") ${ }^{1}$. Furthermore, Table 1 indicates that a service ontology (Moon et al., 2009) has been developed as part of a design support system to increase the reusability of design knowledge. Concerning the individual features, the following features of design objects, originating partly from customization, were observed in these models.

- Moon et al. (2011) developed activity diagrams to represent service process or workflow using UML. The activity diagram enables designers to identify service attributes and activities for performing a whole service.

- Sakao et al. (2007) proposes a degree of satisfaction concerning a specific customer value (i.e., receiver state parameter) for each persona. This degree indicates whether this customer value should be optional.

- Constraints in a design object are observed in (Jiao et al., 2003) in building a variety of structures. There are two types of constraints: restriction on the combination of parameter values and the other is about mapping the relationships of entities.

- Fogliatto and da Silveira (2008) cluster customers to list their attributes and weigh them, and then cluster the customer again based on the weight.

\footnotetext{
${ }^{1}$ Note that Jiao et al. (2003) address service delivery system design as well as product variety but do not use a case to show the application thereof.
} 
In Table 2, the elemental processes of customization are grouped into three phases: 1) Describe design specifications, 2) Derive potential solutions, and 3) Evaluate potential solutions. Table 2 lists the notable features of customization in the evaluation (the line for "3) Evaluate potential solutions") within the customization process. These features are grouped as follows.

- What to customize - Sakao et al. (2007) propose a set of design operations to determine whether to make given values optional based on the degree of value fulfillment. Fogliatto and da Silveira (2008) propose a method to collect preference data from customers and define a choice menu by using statistical analysis. Customers select only what they need or want from a menu based on their own preferences.

- How to customize - Jiao et al. (2003) propose the evaluation of a functionality/technical commonality. Moon et al. (2011) propose a method using a module-based platform strategy and evaluating and prioritizing design costs based on game theory.

Table 1. Concept matrix of existing distinct models for service customization - for inputs to design, design objects, and design support systems

\begin{tabular}{|c|c|c|c|c|}
\hline \multirow{2}{*}{ Element } & \multicolumn{4}{|c|}{ Service } \\
\hline & (Jiao et al., 2003) & (Sakao et al., 2007) & $\begin{array}{l}\text { (Fogliatto and da } \\
\text { Silveira, 2008) }\end{array}$ & (Moon et al., 2011) \\
\hline \multicolumn{5}{|l|}{ Inputs to design } \\
\hline Persona & NA & Persona & Customer cluster & NA \\
\hline Scenario & NA & NA & NA & Activity diagram \\
\hline Constraints & Configuration constraints & NA & NA & NA \\
\hline Others & $\mathrm{NA}$ & Degree of satisfaction & $\mathrm{NA}$ & $\mathrm{NA}$ \\
\hline \multicolumn{5}{|l|}{ Design objects } \\
\hline $\begin{array}{l}\text { Receiver State } \\
\text { Parameter (RSP) }\end{array}$ & Customer benefit & Receiver State Parameter & Preference model & $\begin{array}{l}\text { Customer needs } \\
\text { Functional requirements }\end{array}$ \\
\hline Function & Function feature & $\begin{array}{l}\text { Function of products and } \\
\text { services }\end{array}$ & Attributes & Function \\
\hline \multicolumn{5}{|l|}{ Entity with attributes } \\
\hline Product elements & $\begin{array}{l}\text { Entities } \\
\text { Variety parameters } \\
\text { Product family/platform }\end{array}$ & Entity & Product & NA \\
\hline Service elements & Human resources & Entity & Service & $\begin{array}{l}\text { Service attribute } \\
\text { Module } \\
\text { Service family/platform }\end{array}$ \\
\hline \multicolumn{5}{|l|}{ Delivery process } \\
\hline Product behavior & NA & NA & NA & NA \\
\hline Service activity & $\begin{array}{l}\text { Customer process } \\
\text { Employee process }\end{array}$ & NA & NA & Activity diagram \\
\hline \multicolumn{5}{|l|}{ Design support systems } \\
\hline Case base & NA & NA & NA & NA \\
\hline Ontology & NA & NA & NA & NA \\
\hline $\begin{array}{l}\text { Implementation as } \\
\text { software }\end{array}$ & NA & NA & NA & No \\
\hline Case used & NA & $\begin{array}{l}\text { Customizing hotel } \\
\text { services }\end{array}$ & $\begin{array}{l}\text { Choice menu design in } \\
\text { natural gas service }\end{array}$ & $\begin{array}{l}\text { Banking service family } \\
\text { design }\end{array}$ \\
\hline
\end{tabular}

"NA" represents "not available" (also in Tables 2, 3, 4, 5 and 6). 
Table 2. Concept matrix of existing distinct models for service customization - for design processes

\begin{tabular}{|c|c|c|c|c|}
\hline $\begin{array}{ll}\text { Element } & \text { Model } \\
\end{array}$ & (Jiao et al., 2003) & (Sakao et al., 2007) & $\begin{array}{l}\text { Service } \\
\text { (Fogliatto and da Silveira, } \\
2008)\end{array}$ & (Moon et al., 2011) \\
\hline \multirow{2}{*}{$\begin{array}{l}\text { Describe design specifications } \\
\text { Describe personas }\end{array}$} & & & & \\
\hline & Customer grouping & Describe personas & $\begin{array}{l}\text { Ad-hoc/Formal customer } \\
\text { clustering }\end{array}$ & NA \\
\hline Describe scenarios & NA & NA & NA & Describe activity diagram \\
\hline Describe RSPs & Define customer benefit & Describe RSPs & $\begin{array}{l}\text { Customer involvement } \\
\text { (Questionnaire) } \\
\text { Obtaining attributes from } \\
\text { customers } \\
\text { Create preference model }\end{array}$ & NA \\
\hline \multicolumn{5}{|l|}{ Derive potential solutions } \\
\hline Derive function structures & $\begin{array}{l}\text { Develop } \\
\text { functional/technical } \\
\text { modules }\end{array}$ & $\begin{array}{l}\text { Describe function } \\
\text { structure }\end{array}$ & $\begin{array}{l}\text { Weight attributes } \\
\text { Incorporate process } \\
\text { capacity }\end{array}$ & $\begin{array}{l}\text { Describe function and } \\
\text { process } \\
\text { Create modules }\end{array}$ \\
\hline Derive product elements & $\begin{array}{l}\text { Identify technical } \\
\text { module }\end{array}$ & Describe entities & $\begin{array}{l}\text { Identify attributes for } \\
\text { menus }\end{array}$ & Describe objects \\
\hline Derive service elements & $\begin{array}{l}\text { Identify human } \\
\text { resources }\end{array}$ & Describe entities & $\begin{array}{l}\text { Identify attributes for } \\
\text { menus }\end{array}$ & $\begin{array}{l}\text { Identify objects } \\
\text { Create modules } \\
\text { Module-based approach } \\
\text { (to create service family) } \\
\text { Game-theoretic approach } \\
\text { (platform) }\end{array}$ \\
\hline Derive product behavior & NA & NA & NA & NA \\
\hline Derive service activities & $\begin{array}{l}\text { Identify service delivery } \\
\text { process }\end{array}$ & NA & NA & Develop activity diagram \\
\hline \multirow{2}{*}{$\begin{array}{l}\text { Evaluate potential solutions } \\
\text { Evaluate potential PSS and } \\
\text { select solution }\end{array}$} & & & & \\
\hline & $\begin{array}{l}\text { Evaluate } \\
\text { functional/technical } \\
\text { commonality }\end{array}$ & $\begin{array}{l}\text { Decide whether } \\
\text { RSPs optional }\end{array}$ & $\begin{array}{l}\text { Collect preference data } \\
\text { and define choice menu }\end{array}$ & $\begin{array}{l}\text { Evaluate design cost } \\
\text { Determine platform } \\
\text { strategy }\end{array}$ \\
\hline
\end{tabular}

\subsubsection{PSS customization}

The keyword search of the literature review for PSS customization (described in Section 2) identified five articles as of March 24, 2018. After screening, three articles that present a distinctive model or process (as listed in Tables 3 and 4) from the design science perspective were obtained.

Kuo (2013) did not focus on PSS customization as such but on the development of mass customization and personalization software. However, the software is taken as a product, and software renting and customization are taken as the accompanying services. For example, a renting software service can be viewed as use-oriented PSS. Quality function deployment (QFD) is used in order to obtain customer requirements and transform them into technical attributes. Based on the result of QFD, the designer develops modules including some functions fulfilling customer requirements. These modules are evaluated by ISO/IEC 9126 to determine whether the modules satisfy customers. Finally, cost evaluation is conducted. The result determines whether customers decide to buy or lease the software.

Song and Sakao (2017) developed module-based frameworks for sustainable PSS. They also derived requirements from customers and transformed them into technical attributes. This research uniquely takes technical conflicts into account in the early design phase. For instance, the design attribute of the service response time often conflicts with that of service cost. By considering conflicts, the possible defects in the later design phases can be reduced. Subsequently, PSS components are identified by using a modified service blueprint, and components are clustered into modules. A modified service blueprint is used to derive all the related PSS components such as service processes, service objects, and service resources (Song et al., 2015). The modules are evaluated on the basis of the technical attributes derived from the customer requirements to configure the PSS that fulfills the customer requirements.

A configuration system for PSS customization was proposed (Ming and Liyue, 2011). A meta-ontology for PSS was developed and the structure of the specific PSS is described in ontology web language, and the constraints of the configuration and customer requirements are programmed. Based on this process, configuration is conducted by using the Java expert system shell. Although this method enables rapid configuration, the procedure followed to extract customer requirements and constraints is not described.

Table 3 presents a concept matrix of existing distinct models for PSS customization. Both Ming and Liyue (2011) and Song and Sakao (2017) have PSS elements/components as product or service elements, because PSS is a notion that integrates the product and service. However, these articles focus on the service aspect of PSS rather than on the integration 
of the product and service; in other words, rather than considering the functions of physical products, they consider the service that can be attached to the physical products. Concerning the individual features, the following two features of design objects, originating partly from customization, were observed in these models.

- Customer voices are gathered to know customer needs through a wide variety of sources in (Kuo, 2013).

- Song and Sakao (2017) capture stakeholders' requirements in each of the phases of customer activities by focusing on the lifecycle activities of the product. The customer activity cycle is used to obtain stakeholders' requirements.

Table 4 lists the design processes of PSS customization. The individual features of each model are described below. Ming and Liyue (2011) do not describe object design; thus, all elements are not available. Concerning the individual features, the following two features of a design process, originating partly from customization, were observed in these models.

- Based on the customer voice, QFD is used to transfer the acquired customer needs to technical attributes in (Kuo, 2013).

- Song and Sakao (2017) apply the modified service blueprint to represent the scenario of product use and identify the PSS components including service processes, service objects, etc. 
Table 3. Concept matrix of existing distinct models for PSS customization - for inputs to design, design objects and design support systems

\begin{tabular}{|c|c|c|c|}
\hline \multirow[b]{2}{*}{ Element } & \multicolumn{3}{|c|}{ PSS } \\
\hline & (Ming and Liyue, 2011) & (Kuo, 2013) & (Song and Sakao, 2017) \\
\hline \multicolumn{4}{|l|}{ Inputs to design } \\
\hline Persona & NA & Customer voice & NA \\
\hline Scenario & NA & NA & Customer activity \\
\hline Constraints & Constraints of configuration & Cost & Constraints \\
\hline Others & NA & NA & $\begin{array}{l}\text { Product life cycle information } \\
\text { Conflicts }\end{array}$ \\
\hline \multicolumn{4}{|l|}{ Design objects } \\
\hline $\begin{array}{l}\text { Receiver State Parameter } \\
\text { (RSP) }\end{array}$ & NA & Customer requirements & $\begin{array}{l}\text { PSS requirement } \\
\text { Stakeholders' requirements }\end{array}$ \\
\hline Function & Function & Technical attributes & PSS technical attributes \\
\hline \multicolumn{4}{|l|}{ Entity with attributes } \\
\hline Product elements & PSS element & Modules & PSS component and module \\
\hline Service elements & PSS element & Modules & PSS component and module \\
\hline \multicolumn{4}{|l|}{ Delivery process } \\
\hline Product behavior & NA & NA & $\begin{array}{l}\text { Product using domain and } \\
\text { management domain }\end{array}$ \\
\hline Service activity & NA & NA & $\begin{array}{l}\text { Service processes, objects, } \\
\text { and resources }\end{array}$ \\
\hline \multicolumn{4}{|l|}{ Design support systems } \\
\hline Case base & NA & QFD & NA \\
\hline Ontology & Meta-ontology & NA & NA \\
\hline Implementation as software & Configuration system & NA & NA \\
\hline Case used & $\begin{array}{l}\text { Vehicle total product } \\
\text { configuration }\end{array}$ & $\begin{array}{l}\text { Recyclability evaluation } \\
\text { software }\end{array}$ & Elevator manufacturing \\
\hline
\end{tabular}

Table 4. Concept matrix of existing distinct models for PSS customization - for design processes

\begin{tabular}{|c|c|c|c|}
\hline $\begin{array}{ll}\text { Element } & \text { Model } \\
\end{array}$ & (Ming and Liyue, 2011) & (Kuo, 2013) & (Song and Sakao, 2017) \\
\hline \multicolumn{4}{|l|}{$\begin{array}{l}\text { Describe design } \\
\text { specifications }\end{array}$} \\
\hline Describe personas & NA & $\begin{array}{l}\text { Collect customer voice using } \\
\text { Delphi method }\end{array}$ & NA \\
\hline Describe scenarios & NA & NA & Customer activity cycle \\
\hline Describe RSPs & NA & $\begin{array}{l}\text { Analyze customer requirement } \\
\text { using surveys, focus groups, } \\
\text { interviews and so on }\end{array}$ & PSS requirement mapping \\
\hline \multicolumn{4}{|l|}{ Derive potential solutions } \\
\hline Derive function structures & $\begin{array}{l}\text { Create configuration } \\
\text { model }\end{array}$ & $\begin{array}{l}\text { Transform customer needs into } \\
\text { technical attributes by using } \\
\text { QFD }\end{array}$ & Derive technical attributes \\
\hline Derive product elements & $\begin{array}{l}\text { Obtain from Protégé } \\
\text { ontology }\end{array}$ & Produce modules & $\begin{array}{l}\text { Identify PSS component } \\
\text { Cluster components }\end{array}$ \\
\hline Derive service elements & $\begin{array}{l}\text { Obtain from Protégé } \\
\text { ontology }\end{array}$ & Produce modules & $\begin{array}{l}\text { Identify PSS component } \\
\text { Cluster components }\end{array}$ \\
\hline Derive product behavior & NA & NA & $\begin{array}{l}\text { Derive product using domain } \\
\text { and product management } \\
\text { domain in modified service } \\
\text { blueprint }\end{array}$ \\
\hline Derive service activities & NA & NA & $\begin{array}{l}\text { Derive service processes, } \\
\text { service objects, and service } \\
\text { resources in modified service } \\
\text { blueprint }\end{array}$ \\
\hline \multirow{2}{*}{$\begin{array}{l}\text { Evaluate potential solutions } \\
\text { Evaluate potential PSS and } \\
\text { select a solution }\end{array}$} & & & \\
\hline & $\begin{array}{l}\text { JESS (Java Expert System } \\
\text { Shell) }\end{array}$ & $\begin{array}{l}\text { Evaluation of functions and } \\
\text { modules by experts } \\
\text { Evaluate payoff }\end{array}$ & $\begin{array}{l}\text { Multi-objective configuration } \\
\text { optimization model }\end{array}$ \\
\hline
\end{tabular}




\subsubsection{Product customization}

A literature search of keywords pertaining to product customization, described in Section 2, identified five articles as of March 24, 2018. The following four articles were isolated: (Simpson, 2004), (Jiao et al., 2007), (Fogliatto et al., 2012), and (da Silveira et al., 2001). Note that (da Silveira et al., 2001) has been updated by the same research group (Fogliatto et al., 2012) and thus was only indirectly included. The features in Table 5 and 6 are derived based on the concept of Service Explorer (Hara et al., 2009). Because many features are considered in the targeted review articles, typical features are extracted. The common features of product customizations found in the articles are described below.

The customization of products has been widely researched and reported (Fogliatto et al., 2012). Among others, mass customization (MC) targeting mainly the properties of physical entities was developed (Pine, 1993, Anderson, 1997). In the four review articles, although service is mentioned in connection with products, service design was not addressed. The concept of MC, which is defined as "the design and manufacture of customized products with mass-production levels of efficiency and speed" (Anderson, 1997), is already widespread in industry.

The aim of MC is to satisfy the variable needs and wants of individual customers while maintaining the total economic cost at low levels (e.g., Pine (1993)). In customization, the design of a structure of variable offerings based on a commonly used part is essential because of the economy of scale it offers (Pine, 1993). This common part, known as a "platform," was defined as "a collection of assets that are shared by a set of products" by (Robertson and Ulrich, 1998). This definition could also be applied to services by replacing the term "products" with "services." In the customization of products and services in general, the definition of the assets needed to realize variable offerings while maintaining some of the assets shared by the offerings is essential. In line with the importance of a platform, as described above, component commonality is a fundamental issue, as pointed out by the authors of all three review articles. Furthermore, a balance between component commonality and variety is the key to the design of such platforms (Fogliatto et al., 2012). This is explained as a trade-off between commonality and distinctiveness by (Simpson, 2004) - the nuance of distinctiveness in individual performance rather than merely being different. There are three types of approaches for achieving this (Fogliatto et al., 2012): (i) optimization-based approaches, (ii) commonality index-based approaches, and (iii) approaches based on other indices. For optimization-based approaches, more than half adopt multi-objective optimization as reviewed by (Simpson, 2004). Concerning the indexes, important indexes (Simpson, 2004, Jiao et al., 2007) are cost, profit, and platform-related indexes. Platform-related indexes include: platform efficiency and platform effectiveness (Jiao et al., 2007).

Other fundamental issues include product architecture and modularity (Jiao et al., 2007). Modularity involves separating a system into independent parts or modules that can be treated as logical units (Newcomb et al., 1996). Important for the characterization of modularity is the interaction between the modules. Modules are identified such that between-module (intermodule) interactions are minimal whereas within-module (intra-module) interactions can be high (Ulrich and Eppinger, 2000); therefore, decomposition is the main concern of modularity.

More specifically, different approaches for leveraging a platform in terms of customer segments and levels of cost and performance were summarized (Simpson, 2004): (a) horizontal leveraging meaning that a platform is used for different customer segments without changing the levels of cost or performance, e.g., using a low-end platform, (b) vertical leveraging meaning that a platform is used for different levels of cost and performance within the same customer segment, e.g., scale-down in terms of the level of cost and performance within the segment, and (c) a hybrid of (a) and (b).

Two strategies for implementing platform-based product family design are known, namely module-based product family design (product family members are composed by adding, substituting, and/or removing one or more functional modules), and scale-based product family design (scaling variables are used to stretch or shrink the product platform in one or more dimensions to satisfy a variety of market niches) (Simpson, 2004, Jiao et al., 2007). Although some researchers consider scale-based product family design to be a subset of module-based product family design(Fujita and Yoshida, 2001), both the former and latter strategies are popular in many industries (Simpson, 2004). 
Table 5. Concept matrix of existing distinct models for product customization - for inputs to design, design objects and design support systems

\begin{tabular}{|c|c|c|c|}
\hline \multirow[b]{2}{*}{ Element } & \multicolumn{3}{|c|}{ Product } \\
\hline & (Simpson 2004) & (Jiao et al. 2007) & $\begin{array}{l}\text { (Fogliatt et al., 2012), and (da } \\
\text { Silveira et al., 2001) }\end{array}$ \\
\hline \multicolumn{4}{|l|}{ Inputs to design } \\
\hline Persona & Market segment or niches & Segmentation of market & Group of customers \\
\hline Scenario & NA & $\mathrm{NA}$ & NA \\
\hline Constraints & Constraints & Constraints & Supplier constraints \\
\hline Others & NA & NA & NA \\
\hline \multicolumn{4}{|l|}{ Design objects } \\
\hline Receiver State Parameter (RSP) & Customer needs & $\begin{array}{l}\text { Customer needs } \\
\text { Customer preference }\end{array}$ & $\begin{array}{l}\text { Customer demand } \\
\text { Customer preference } \\
\text { Specification }\end{array}$ \\
\hline Function & Function elements & $\begin{array}{l}\text { Function requirement } \\
\text { Design parameter }\end{array}$ & Function requirement \\
\hline \multicolumn{4}{|l|}{ Entity with attributes } \\
\hline Product elements & $\begin{array}{l}\text { Physical structure } \\
\text { Module (module-based) } \\
\text { Variable (scale-based) } \\
\text { Product family/platform }\end{array}$ & $\begin{array}{l}\text { Component } \\
\text { Module (module-based) } \\
\text { Variable (scale-based) } \\
\text { Product family/platform }\end{array}$ & $\begin{array}{l}\text { Component } \\
\text { Product family/platform }\end{array}$ \\
\hline Service elements & Service & Service & Service \\
\hline Delivery process & & & \\
\hline Product behavior & NA & NA & $\begin{array}{l}\text { Standard product can be altered by } \\
\text { customers during use }\end{array}$ \\
\hline Service activity & NA & NA & NA \\
\hline \multicolumn{4}{|l|}{ Design support systems } \\
\hline Case base & $\begin{array}{l}\text { QFD } \\
\text { Modular function development }\end{array}$ & $\begin{array}{l}\text { QFD, MDF and DSM (to make } \\
\text { module) }\end{array}$ & NA \\
\hline Ontology & NA & NA & NA \\
\hline Implementation as software & $\begin{array}{l}\text { Automatic product configuration } \\
\text { and automatic computer-aided } \\
\text { design (CAD) modeling and }\end{array}$ & $\begin{array}{l}\text { Module design support systems } \\
\text { Online product configurators }\end{array}$ & $\begin{array}{l}\text { Advanced manufacturing } \\
\text { technologies (e.g., CNC, CAD, } \\
\text { CAM, CIM and EDI) }\end{array}$ \\
\hline & $\begin{array}{l}\text { geometry generation } \\
\text { Web-based customization } \\
\text { contributes to one-to-one } \\
\text { marketing because of its efficient } \\
\text { information technology }\end{array}$ & & $\begin{array}{l}\text { Information technology creating } \\
\text { database of customers and enabling } \\
\text { orders to be fulfilled correctly }\end{array}$ \\
\hline Case used & NA & NA & NA \\
\hline
\end{tabular}

Table 6. Concept matrix of existing distinct models for product customization - for design processes

\begin{tabular}{|c|c|c|c|}
\hline \multirow[b]{2}{*}{ Element } & \multicolumn{3}{|c|}{ Product } \\
\hline & (Simpson, 2004) & (Jiao et al., 2007) & $\begin{array}{l}\text { (Fogliatto et al., 2012), and (da } \\
\text { Silveira et al., 2001) }\end{array}$ \\
\hline \multirow{2}{*}{\multicolumn{4}{|c|}{$\begin{array}{l}\text { Describe design specifications } \\
\text { Describe personas }\end{array}$}} \\
\hline & NA & Market segmentation of market & Fuzzy clustering based on preference \\
\hline Describe scenarios & NA & NA & NA \\
\hline Describe RSPs & Customer involvement & $\begin{array}{l}\text { Derive representative customer needs } \\
\text { from market segment }\end{array}$ & Customer involvement \\
\hline \multicolumn{4}{|l|}{ Derive potential solutions } \\
\hline Derive function structures & NA & $\begin{array}{l}\text { Translate customer needs to function } \\
\text { requirement } \\
\text { Mapping function requirement to } \\
\text { design parameter }\end{array}$ & Develop function \\
\hline Derive product elements & $\begin{array}{l}\text { Mapping of function elements to } \\
\text { physical elements } \\
\text { Module-based/Scale-based (product } \\
\text { family) } \\
\text { Find commonly used parts } \\
\text { (platform) }\end{array}$ & $\begin{array}{l}\text { Mapping from function to component } \\
\text { Module-based/Scale-based (product } \\
\text { family) } \\
\text { Find commonly used parts (platform) }\end{array}$ & $\begin{array}{l}\text { Make module } \\
\text { Find commonly used parts (platform) }\end{array}$ \\
\hline Derive service elements & NA & NA & NA \\
\hline Derive product behavior & NA & NA & NA \\
\hline Derive service activities & NA & NA & NA \\
\hline \multicolumn{4}{|l|}{ Evaluate potential solutions } \\
\hline $\begin{array}{l}\text { Evaluate potential PSS and } \\
\text { select a solution }\end{array}$ & $\begin{array}{l}\text { Trade-off between commonality } \\
\text { and distinctiveness } \\
\text { Optimize commonality level to help } \\
\text { identify which variables to make } \\
\text { common and unique within the } \\
\text { family }\end{array}$ & $\begin{array}{l}\text { Determining the right amount of } \\
\text { decomposition (modularity) } \\
\text { Determine optimal level of } \\
\text { commonality }\end{array}$ & $\begin{array}{l}\text { Balance between component } \\
\text { commonality and variety } \\
\text { - Optimization-based approaches } \\
\text { - Commonality index-based } \\
\text { approaches } \\
\text { - Others }\end{array}$ \\
\hline
\end{tabular}




\section{Discussion}

\subsection{Comparison and analysis of customization of product, service, and PSS}

The center column of Table 7 and Table 8 comparatively describes the customization of products, services, and PSSs. The rightmost column presents an analysis to enhance the customization of PSS. Table 7 includes inputs to design, design objects, and design support systems, whereas Table 8 covers design processes. An overview is given below, and details are provided in the two respective tables.

Considering the design process, each reported study adopted a different method to design offerings, but some methods can be utilized in either service or PSS. For example, in the case of PSS, customer clustering as used in services (Fogliatto and da Silveira, 2008) is not implemented in PSS but it may be an efficient method to understand customers. On the other hand, in PSS, a modified service blueprint was used to derive product and service behavior (Song and Sakao, 2017), and this method can be used for either services or products to promote the value of an offering by considering the interaction between the offering and the customer.

Customization often involves the creation of modules to customize parts based on customer needs, and especially in PSS, modules are created mainly in relation to services. The creation of a module, namely modularity, has been extensively discussed in the case of products. On the other hand, for PSS, insufficient discussion about modularity seems to have taken place and this should be promoted in future. Moreover, when developing PSS modules, consideration of the relation between products and services would stimulate the development of a PSS that is more highly integrated and effective.

As described in Section 3.2.3 and under "Derive product elements" in Table 8 (b), two strategies can be followed for product family design, namely module-based product family design, whereby product family members are composed by adding, substituting, and/or removing one or more functional modules, and scale-based product family design, whereby scaling variables are used to stretch or shrink the product platform in one or more dimensions to satisfy a variety of market niches (Simpson, 2004, Jiao et al., 2007). In service customization, Moon et al. (2011) adopted a module-based platform. Fogliatto and da Silveira (2008) did not use a module-based platform, but created a choice menu that contains many options created based on customer preference, which can be similar to creating modules. However, in service customization, the scale-based platform is not adopted, because service components are often regarded as less-scalable entities than product components. Moreover, the module-based platform seems to be suitable for PSS customization because PSS contains a service component (Sakao et al., 2017). However, different research groups on PSS (Kowalkowski et al., 2015, Raja et al., 2017) have recently shown that service scalability could grow businesses. 
Table 7 (a). Descriptive comparison and analysis of customization of products, services, and PSSs - for inputs to design, design objects and design support systems

\begin{tabular}{|c|c|c|}
\hline Element & Descriptive comparison & Analysis \\
\hline \multicolumn{3}{|l|}{ Inputs to design } \\
\hline \multirow[t]{2}{*}{ Persona } & Services and PSSs are similar. & $\begin{array}{l}\text { Current research results sensible: understanding customer/user } \\
\text { characteristics/values is critical. }\end{array}$ \\
\hline & $\begin{array}{l}\text { Services use customer clusters. Products use } \\
\text { market segments. }\end{array}$ & $\begin{array}{l}\text { PSS and services require a more detailed understanding of } \\
\text { customers than products. Further, in the case of products, the } \\
\text { number of customers is greater than in PSSs and services. } \\
\text { Hence, market segments have rougher granularity. }\end{array}$ \\
\hline \multirow[t]{2}{*}{ Scenario } & Services and PSSs are similar. & \multirow{2}{*}{$\begin{array}{l}\text { Current research results sensible: describing and understanding } \\
\text { customer behavior is more important for service and PSS due } \\
\text { to co-creation characteristics than for product. }\end{array}$} \\
\hline & $\begin{array}{l}\text { For products, no such a concept is explicitly } \\
\text { addressed. }\end{array}$ & \\
\hline \multirow[t]{2}{*}{ Constraints } & Considered for both products and PSSs. & $\begin{array}{l}\text { For products, constraints are important because products are } \\
\text { physical. For PSS, intangible constraints are considered to } \\
\text { improve the effectiveness of PSS offerings. }\end{array}$ \\
\hline & Services do not have this concept. & $\begin{array}{l}\text { Constraints not considered in services because of their } \\
\text { intangibility. Constraints could be introduced in services in a } \\
\text { similar way as in PSSs. }\end{array}$ \\
\hline \multirow[t]{2}{*}{ Others } & $\begin{array}{l}\text { Degree of satisfaction (Sakao et al., 2007) is } \\
\text { unique in service. }\end{array}$ & Degree of satisfaction could be utilized in PSS. \\
\hline & $\begin{array}{l}\text { Product lifecycle information and conflicts } \\
\text { are considered only in PSS (Song and Sakao, } \\
\text { 2017). }\end{array}$ & $\begin{array}{l}\text { When PSS is attempted with a lifecycle approach, addressing } \\
\text { conflicts between lifecycle stages is sensible. }\end{array}$ \\
\hline \multicolumn{3}{|l|}{ Design objects } \\
\hline \multirow[t]{2}{*}{$\begin{array}{l}\text { Receiver State } \\
\text { Parameter (RSP) }\end{array}$} & $\begin{array}{l}\text { Similar concepts are used in products, } \\
\text { services, and PSSs. }\end{array}$ & \multirow{2}{*}{$\begin{array}{l}\text { More stakeholders are involved and influenced throughout a } \\
\text { PSS lifecycle (Durugbo et al., 2011), and thus addressing } \\
\text { stakeholders' requirements is crucial. }\end{array}$} \\
\hline & $\begin{array}{l}\text { Stakeholders' requirements are addressed } \\
\text { only in PSS (Song and Sakao 2017). }\end{array}$ & \\
\hline Function & Addressed in products, services, and PSSs. & $\begin{array}{l}\text { Current research result sensible: designing for a required } \\
\text { function is essential to create all offerings. }\end{array}$ \\
\hline \multicolumn{3}{|c|}{ Entity with attributes } \\
\hline \multirow[t]{4}{*}{ Product elements } & $\begin{array}{l}\text { Both PSSs and products consider product } \\
\text { elements, but in PSS, the product and service } \\
\text { elements are also integrated into one } \\
\text { element. }\end{array}$ & $\begin{array}{l}\text { Current PSS research sensible: PSS integration product and } \\
\text { service should consider both elements simultaneously. }\end{array}$ \\
\hline & $\begin{array}{l}\text { In services, Fogliatto and da Silveira (2008) } \\
\text { and (Jiao et al., 2003) address product } \\
\text { elements. }\end{array}$ & $\begin{array}{l}\text { In services, Fogliatto and da Silveira (2008) seem to integrate } \\
\text { products and services. Their study can be seen as targeting a } \\
\text { result-oriented PSS. Services sometimes seem to include a } \\
\text { product component because products are often used in services. }\end{array}$ \\
\hline & $\begin{array}{l}\text { In products, variables are considered (Jiao et } \\
\text { al., 2003)(Simpson, 2004). }\end{array}$ & $\begin{array}{l}\text { In products, variables that stretch or shrink based on customer } \\
\text { needs are considered in the context of a scale-based product } \\
\text { family (Jiao et al., 2003)(Simpson, 2004). This is unique to } \\
\text { products because the parameters of service elements cannot be } \\
\text { stretched or shrunk in the same way as for product elements. }\end{array}$ \\
\hline & $\begin{array}{l}\text { Products: product family (module-based and } \\
\text { scale-based) and platform (the fundamental } \\
\text { concept of mass customization) are created. } \\
\text { Services: (Moon et al., 2011) used a service } \\
\text { family and platform. }\end{array}$ & $\begin{array}{l}\text { Family design and platform design are essential in mass } \\
\text { customization. These concepts are related with module design. } \\
\text { PSS customization has scope for further research in both family } \\
\text { and platform design. }\end{array}$ \\
\hline \multirow[t]{2}{*}{ Service elements } & $\begin{array}{l}\text { Addressed in both services and PSSs. } \\
\text { PSS: service and product elements are } \\
\text { considered. }\end{array}$ & $\begin{array}{l}\text { Products focus on the product, whereas services include both } \\
\text { products and services. } \\
\text { Current PSS research makes sense: an integration of products } \\
\text { and services should consider both elements simultaneously. }\end{array}$ \\
\hline & Products also include service elements. & $\begin{array}{l}\text { In terms of products, services are considered, but the design of } \\
\text { the service is not described. This is sensible because product } \\
\text { customization is the main concern. }\end{array}$ \\
\hline
\end{tabular}


Table 7 (b). Descriptive comparison and analysis of customization of products, services, and PSSs - for inputs to design, design objects and design support systems

\begin{tabular}{|c|c|c|}
\hline Element & Descriptive comparison & Analysis \\
\hline \multicolumn{3}{|l|}{ Delivery process } \\
\hline \multirow[t]{3}{*}{ Product behavior } & $\begin{array}{l}\text { Only in PSS is product behavior explicitly } \\
\text { addressed. }\end{array}$ & $\begin{array}{l}\text { Current PSS research is sensible: PSSs are developed together } \\
\text { with the associated product behavior, which has a large impact } \\
\text { on PSS. }\end{array}$ \\
\hline & $\begin{array}{l}\text { For products, product behavior during the use } \\
\text { phase is addressed. }\end{array}$ & $\begin{array}{l}\text { Product usage is altered by customers during the usage phase, } \\
\text { but the design of product behavior is not explicitly addressed } \\
\text { in the context of product customization. Product behavior } \\
\text { during the usage phase may be considered in detailed product } \\
\text { design, although it does not seem to be mentioned in the } \\
\text { context of customization. Product behavior during usage can } \\
\text { facilitate the valuation of offerings. }\end{array}$ \\
\hline & Not considered in service. & $\begin{array}{l}\text { Note that Jiao et al. (2003) address service delivery system } \\
\text { design and product variety without applying it to a case. } \\
\text { Product behavior could also be addressed in services. }\end{array}$ \\
\hline \multirow[t]{2}{*}{ Service activity } & $\begin{array}{l}\text { Processes involving customers and } \\
\text { employees are addressed in services (Jiao et } \\
\text { al., 2003). An activity diagram is used in } \\
\text { service (Moon et al., 2011). }\end{array}$ & $\begin{array}{l}\text { Current research results make sense: customer needs are } \\
\text { fulfilled during each service process; considering service } \\
\text { activity is important in both services and PSSs. }\end{array}$ \\
\hline & $\begin{array}{l}\text { Service processes and resources are } \\
\text { addressed in PSS (Song and Sakao, 2017). } \\
\text { No similar concept is touched upon in } \\
\text { products. }\end{array}$ & $\begin{array}{l}\text { Song and Sakao (2017) clarified the limitation of resources } \\
\text { and design resource allocation in order to create feasible } \\
\text { solutions. This could also be used in services. }\end{array}$ \\
\hline \multicolumn{3}{|c|}{ Design support systems } \\
\hline Case base & $\begin{array}{l}\text { QFD is applied in PSS and products. } \\
\text { In products, several methods are utilized to } \\
\text { create modules. }\end{array}$ & $\begin{array}{l}\text { Methods used for products should be applied to PSS and } \\
\text { services, respectively, after customization. }\end{array}$ \\
\hline Ontology & Ontology is used explicitly in PSS. & An opportunity for future research exists. \\
\hline $\begin{array}{l}\text { Implementation } \\
\text { as software }\end{array}$ & In products, some software is used. & $\begin{array}{l}\text { In PSS and services, software support decreases the difficulty } \\
\text { for designers to customize offerings. This is an opportunity for } \\
\text { future research. }\end{array}$ \\
\hline Cases used & $\begin{array}{l}\text { In services, cases of hotel services (Sakao et } \\
\text { al., 2007), natural gas services (Fogliatto and } \\
\text { da Silveira, 2008), and banking services } \\
\text { (Moon et al., 2011) are used. } \\
\text { In PSS, cases of vehicles (Ming and Liyue, } \\
\text { 2011), software (Kuo, 2013), and elevators } \\
\text { (Song and Sakao 2017) are used. }\end{array}$ & $\begin{array}{l}\text { In services, the case of natural gas also includes product } \\
\text { characteristics (Fogliatto and da Silveira, 2008) and could be } \\
\text { applied to PSS customization. }\end{array}$ \\
\hline
\end{tabular}


Table 8 (a). Descriptive comparison and analysis of customization of products, services, and PSSs - for design processes

\begin{tabular}{|c|c|c|}
\hline Element & Descriptive comparison & Analysis \\
\hline \multicolumn{3}{|c|}{ Describe design specifications } \\
\hline \multirow[t]{2}{*}{ Describe personas } & $\begin{array}{l}\text { Similar methods used in services and } \\
\text { products. Customer clustering (Fogliatto } \\
\text { and da Silveira, 2008) and grouping (Jiao et } \\
\text { al., 2003) used in services; market segments } \\
\text { created for products (Jiao et al. 2007). }\end{array}$ & $\begin{array}{l}\text { Customer clustering (Fogliatto and da Silveira, 2008), } \\
\text { grouping (Jiao et al., 2003), and market segmentation } \\
\text { (Jiao et al. 2007) could be used in PSS. } \\
\text { Market segments for products may include large groups of } \\
\text { customers. For mass customers in services and PSSs, } \\
\text { creating market segments could be effective. }\end{array}$ \\
\hline & $\begin{array}{l}\text { Delphi method used as a concrete method in } \\
\text { PSS (Kuo, 2013). }\end{array}$ & $\begin{array}{l}\text { Collecting the customer voice by using the Delphi method } \\
\text { (Kuo, 2013) could also be applied to services. }\end{array}$ \\
\hline \multirow[t]{2}{*}{ Describe scenarios } & $\begin{array}{l}\text { Conducted in services and PSSs; activity } \\
\text { diagram used in services (Moon et al., } \\
\text { 2011); customer activity cycle used in PSS } \\
\text { (Song and Sakao 2017). }\end{array}$ & $\begin{array}{l}\text { Activity diagram (Moon et al., 2011) used in PSS; } \\
\text { customer activity cycle (Song and Sakao 2017) used for } \\
\text { services. }\end{array}$ \\
\hline & $\begin{array}{l}\text { Methods describing customer behavior not } \\
\text { explicitly addressed for products. }\end{array}$ & $\begin{array}{l}\text { Product behavior during the usage phase may be } \\
\text { considered in detailed product design, but does not seem } \\
\text { to be mentioned in the context of customization. Product } \\
\text { behavior during usage can facilitate the valuation of } \\
\text { offerings even in the context of customization. }\end{array}$ \\
\hline \multirow[t]{2}{*}{ Describe RSPs } & $\begin{array}{l}\text { Similar processes implemented in services } \\
\text { and PSSs: every process aims to clarify } \\
\text { customer needs. }\end{array}$ & $\begin{array}{l}\text { Similarity of services and PSSs is sensible: clarifying } \\
\text { customer needs is essential for both. }\end{array}$ \\
\hline & $\begin{array}{l}\text { Customer involvement used in services and } \\
\text { products (Fogliatto and da Silveira, } \\
\text { 2008)(Simpson, 2004)(Fogliatto et al., } \\
\text { 2012). PSS: customer involvement methods } \\
\text { such as surveys, focus groups, and } \\
\text { interviews are also used (Kuo, 2013). }\end{array}$ & $\begin{array}{l}\text { Customer involvement: essential to capture customer } \\
\text { needs in all customization. }\end{array}$ \\
\hline
\end{tabular}


Table 8 (b). Descriptive comparison and analysis of customization of products, services, and PSSs - for design processes

\begin{tabular}{|c|c|c|}
\hline Element & Descriptive comparison & Analysis \\
\hline \multicolumn{3}{|c|}{ Derive potential solutions } \\
\hline \multirow[t]{2}{*}{$\begin{array}{l}\text { Derive function } \\
\text { structures }\end{array}$} & $\begin{array}{l}\text { Similar processes, transforming customer } \\
\text { needs into functions, are implemented in all } \\
\text { customizations. }\end{array}$ & $\begin{array}{l}\text { Current research results make sense: it is essential to } \\
\text { derive required functions based on customer needs. }\end{array}$ \\
\hline & $\begin{array}{l}\text { The use of weighting attributes (Fogliatto } \\
\text { and da Silveira, 2008) is unique in services. }\end{array}$ & $\begin{array}{l}\text { Weighting service attributes directly derived from } \\
\text { customers' inputs without considering e.g., the function } \\
\text { structure (Fogliatto and da Silveira, 2008) may be possible } \\
\text { because services are less complex than in PSSs: conflicts } \\
\text { between attributes are more likely to occur in PSSs. }\end{array}$ \\
\hline \multirow[t]{2}{*}{$\begin{array}{l}\text { Derive product } \\
\text { elements }\end{array}$} & $\begin{array}{l}\text { In both PSSs and products, functions are } \\
\text { transformed into product elements (Song } \\
\text { and Sakao, 2017) (Jiao et al., 2007) and } \\
\text { modules are created (Kuo, 2013) (Song and } \\
\text { Sakao, 2017) (Simpson, 2004) (Jiao et al. } \\
\text { 2007). }\end{array}$ & $\begin{array}{l}\text { Clustering elements seem to be a common way to create } \\
\text { modules. In products, discussions of module development } \\
\text { are effective. However, this seems to be underdeveloped } \\
\text { in PSSs. } \\
\text { In services, when products are included in an offering, } \\
\text { product elements could also be derived. }\end{array}$ \\
\hline & $\begin{array}{l}\text { Platform strategy is used for products: } \\
\text { module-based and scale-based strategies } \\
\text { (Simpson, 2004) (Jiao et al., 2007). }\end{array}$ & $\begin{array}{l}\text { Module-based strategy is also used for services (Moon et } \\
\text { al., 2011). Scale-based strategy can be difficult to adapt to } \\
\text { services and PSSs because elements of services are not } \\
\text { scalable. }\end{array}$ \\
\hline \multirow[t]{3}{*}{$\begin{array}{l}\text { Derive service } \\
\text { elements }\end{array}$} & $\begin{array}{l}\text { Modules and elements of services are } \\
\text { considered in services and PSSs (Moon et } \\
\text { al., 2011) (Kuo, 2013) (Song and Sakao, } \\
\text { 2017). }\end{array}$ & $\begin{array}{l}\text { Both services and PSSs seem to be largely based on } \\
\text { product customization methods. However, creating service } \\
\text { modules is underdeveloped compared to products. }\end{array}$ \\
\hline & $\begin{array}{l}\text { Creating a choice menu is unique for } \\
\text { services (Fogliatto and da Silveira, 2008). } \\
\text { For products, nothing is stated explicitly. }\end{array}$ & The choice menu could be adopted for PSS. \\
\hline & $\begin{array}{l}\text { A module-based platform strategy is used } \\
\text { for services. }\end{array}$ & $\begin{array}{l}\text { Discussion of modularity should be stimulated more in the } \\
\text { context of service and PSS customization. }\end{array}$ \\
\hline \multirow[t]{2}{*}{$\begin{array}{l}\text { Derive product } \\
\text { behaviors }\end{array}$} & $\begin{array}{l}\text { No similar process is touched upon in } \\
\text { connection with services and products. }\end{array}$ & $\begin{array}{l}\text { In services and products, methods such as modified } \\
\text { service blueprints could derive product behavior and } \\
\text { describe interactions between offerings and customers. }\end{array}$ \\
\hline & $\begin{array}{l}\text { Only in PSS, product behavior is considered } \\
\text { in a modified service blueprint (Song and } \\
\text { Sakao, 2017). }\end{array}$ & $\begin{array}{l}\text { It is sensible that PSS considers product behavior, because } \\
\text { services in PSS are strongly related to product behavior. }\end{array}$ \\
\hline \multirow[t]{2}{*}{$\begin{array}{l}\text { Derive service } \\
\text { activities }\end{array}$} & $\begin{array}{l}\text { Service processes are derived for both } \\
\text { services and PSSs. An activity diagram is } \\
\text { used for services (Moon et al., 2011). }\end{array}$ & $\begin{array}{l}\text { In service customization, only an activity diagram is used } \\
\text { explicitly to derive service activity, and this is a future } \\
\text { research opportunity: Service blueprint is used in service } \\
\text { design and could be used also in service customization. }\end{array}$ \\
\hline & $\begin{array}{l}\text { A modified service blueprint is used only in } \\
\text { PSS (Song and Sakao, 2017). } \\
\text { This is not discussed for products. }\end{array}$ & $\begin{array}{l}\text { In products, methods such as a modified service blueprint } \\
\text { could be used to describe interaction between product and } \\
\text { customers. }\end{array}$ \\
\hline \multicolumn{3}{|c|}{ Evaluate potential solutions } \\
\hline \multirow[t]{2}{*}{$\begin{array}{l}\text { Evaluate potential } \\
\text { PSS and select a } \\
\text { solution }\end{array}$} & $\begin{array}{l}\text { Solutions are created through evaluation or } \\
\text { optimization of modules/components. } \\
\text { Evaluations are implemented quantitatively } \\
\text { or qualitatively. } \\
\text { PSS: qualitative evaluation was conducted } \\
\text { (Kuo, 2013): experts evaluate functions and } \\
\text { modules. Services: deciding whether } \\
\text { creating RSPs are optional is conducted } \\
\text { qualitatively based on the extent of } \\
\text { satisfaction (Sakao et al., 2007). } \\
\text { Others are evaluated quantitatively. }\end{array}$ & $\begin{array}{l}\text { Current research results make sense: customized offerings } \\
\text { should be optimized to fulfill specific customer needs. } \\
\text { Evaluation by experts could be used for services and } \\
\text { products especially when insufficient data are available. }\end{array}$ \\
\hline & $\begin{array}{l}\text { For products, modularity and commonality } \\
\text { are evaluated. }\end{array}$ & $\begin{array}{l}\text { Discussion of modularity should be stimulated more in the } \\
\text { context of service and PSS customization. }\end{array}$ \\
\hline
\end{tabular}




\subsection{Future research opportunities for PSS customization}

General discussions of Tables 7 and 8 are presented below to highlight relevant future research directions in PSS customization. PSS customization can be more complex than service and product customization because PSS contains service and product components. PSS contains some unique characteristics that are implemented to ensure that the PSS is effective, such as considering the usage phase, lifecycle perspective, stakeholders, and product behavior. However, research relating to PSS customization has focused mainly on the service aspect of PSS.

In fact, as the customization of PSS has not been thoroughly investigated yet, valuable insights for PSS customization can be obtained from both product customization, on which many researchers have been focusing for decades, and service customization, which can be an important strategy to satisfy customers' needs (Moon et al., 2011). Future research opportunities are described below. Focusing on PSS customization, researchers mainly discuss services added to existing products and add value to products for customers (Fargnoli et al., 2018); i.e., research aimed at integrating products and services involving interchange between them has not been reported yet. Such a method would enable manufacturers to create effective and highly integrated customized PSSs. Hara et al. (2009) developed Service Explorer, which enables designers to integrate value design, service-activity design, and product design. However, Service Explorer is not aimed at customization. Ways to consider product behavior and functions when creating new customized PSS could be worth researching.

Forming customer groups, such as customer clustering (Fogliatto and da Silveira, 2008), grouping (Jiao et al., 2003), and market segmentation (Jiao et al., 2007), has been used in connection with both products and services. On the other hand, PSS focuses on individual customers. This is sensible because the number of customers in the case of PSS has been low and is not sensible to create customer groups. When using PSS for large numbers of customers, however, customer clustering could be effective. Other methods used for services, such as considering the degree of satisfaction to decide what should be customized and using an activity diagram to understand customers and service activity, could also be useful for PSS. A choice menu (Fogliatto and da Silveira, 2008), which enables customers to choose their service and product, can also be effective to design customized PSS.

Product development often uses a design support system; however, such systems are not developed for services and PSSs despite the difficulties associated with the design of customized services and PSSs. In PSS and services, software support can be expected to facilitate the design of customized offerings and presents an opportunity for future research. Family design is a key issue in product customization. In services and PSS, discussion of family design (including scalebased family design) is insufficient and would need to include modularity.

As mentioned in Section 4.1, PSS modularity has not yet been discussed sufficiently. This would be an interesting study area in PSS customization because modularity is likely to contribute to the efficient and effective creation of customized PSS. Because services are characterized by intangibility, research relating to service modularity would be useful for PSS modularity. This issue is elaborated in the next section.

\subsection{Module-based PSS design}

This section addresses module-based PSS design as a large area for future research. According to Brax et al. (2017), issues of service modularity have recently responded to the growing demand for architectural and design knowledge. They also stated that PSS modularity is a fertile area to be researched. Services have learned much from product customization, which has been researched extensively. Similarly, PSS can learn from product and service modularity.

Service modularity is the focus of various kinds of service areas, e.g., healthcare, logistics, and finance, because of the heterogeneity of the context in which the concepts can be applied (Brax et al., 2017). This also applies to PSS, which can be implemented in various ways and additional case studies are necessary. In the service context, Broekhuis et al. (2017) adopted modularity principles derived in the context of product modularity to design modular service architecture for elderly care. The modularity principles are that modules should have a specific function, be relatively independent, and have standardized interfaces for integration purposes (Ulrich, 1995, Baldwin and Clark, 2000, Schilling, 2000). As a result, the adoption of the "relative independence" and "standardized interfaces" principles are fairly limited because the design choices are highly intertwined and this is inherent to the nature of service modularity.

Visintin (2012) conducted a case study of PSS customization in the printing industry, where Océ, the case company, 
manufactures hardware and software components separately, and the relations between them are well understood. Furthermore, Océ creates several types of delivery processes, including orientation, analysis, design, implementation and support, which can be chosen based on individual customer needs. This method enabled Océ to create highly customized solutions. Creating product and service modules separately and understanding their relation to each other would be a good way to ease the difficulty of PSS modularity. In addition, selectable delivery processes ensure that solutions are more effective for customers. Although this method would be effective for PSS customization, additional research in different industries would be necessary.

Sakao et al. (2017) proposed a practical method to create service modules of PSS by extending the DSM (Design Structure Matrix). They focused on the service aspect of a PSS offering and create "service" modules that contain service components rather than product components. As Brax et al. (2017) pointed out, PSS modules can be complex because they contain a mixture of product and service components. From this perspective, no practical methods have been proposed to create modules containing both service and product elements. This provides a concrete future research opportunity.

\subsection{Future research opportunities for product and service customization}

Based on Tables 7 and 8, future research opportunities for product and service customization are derived by comparing PSS, service, and product customization.

\subsubsection{Service customization}

Intangible constraints can be addressed in services during the design phase in the same way as in PSS (Song and Sakao, 2017), e.g., the limitation of personnel resources, in order to create feasible solutions. Methods that are used in PSS to understand customers, i.e., the Delphi method (Kuo, 2013) and customer activity cycle (Vandermerwe, 1993), should also be useful in services. In addition, in PSS, the modified service blueprint (after (Shostack, 1982)) is used to derive product behavior and describe interaction between offerings and customers (Song and Sakao, 2017). However, in services, a specific way to derive service activity is not addressed and this is a future research opportunity: A service blueprint is used in service design and could be used in service customization.

\subsubsection{Product customization}

Some concepts used in services or PSSs, but not products, are included in Table 7 and Table 8. Because there are some characteristics of services, e.g., that a more detailed understanding of the customer is needed than for products, some concepts are available only in services or PSS. Some future research opportunities found in product customization as explained below.

Product lifecycle information used in services (Song and Sakao, 2017) can be adopted as an input to design conducted in product customization. This is expected to contribute to higher value and resource efficiency, because the designer can pay more attention to each phase of product life and find hidden customer needs and an alternative efficient use of materials. This contribution is relevant because lifecycle is regarded as important even in product design (Umeda et al., 2012). In addition, some methods such as a modified service blueprint could be used to derive product behavior and describe interaction between offerings and customers. This would enable designers to devote more attention to the usage phase. Lastly, in product design, product behavior during the usage phase may be considered in detailed design, yet it does not seem to be mentioned in the context of customization. Understanding product behavior during usage can facilitate the validation of offerings.

\subsection{Contribution to the environmental performance}

Except for Song and Sakao (2017), no researchers have reported the influence of PSS customization on environmental performance. PSS customization can have a positive effect on the environment because PSS itself is expected to create an impact on environmental gain (Tukker, 2004). In addition, customization of PSS may further enhance the environmental aspect. Therefore, this matter needs further investigation and it could be a driver for manufacturers to promote PSS customization. 


\section{Conclusion}

This research has reviewed literature about service, product, and PSS customization to identify research opportunities in the context of PSS customization. Although service and product customization has received wide attention, PSS customization has been underexplored, and some papers discussing PSS customization only focus on PSS from a service perspective. To advance the knowledge for PSS customization, building upon extant methods for PSS design, which consider functions of both products and services and exploit the inter-relations among them, could be effective. This review showed concrete future research opportunities such as integration of products and services during PSS customization, application of customer clustering in PSS, development of design support software for PSS customization, development a concept of PSS family design, and development of a PSS-modularity concept.

\section{Acknowledgement}

The second author was supported in part by the Circularis (Circular Economy through Innovating Design) project funded by VINNOVA, Sweden's Innovation Agency (No. 2016-03267).

\section{References}

Akasaka, F., Nemoto, Y., Kimita, K. and Shimomura, Y., Development of a knowledge-based design support system for Product-Service Systems, Computers in Industry, Vol. 63 (2012), pp. 309-318.

Alonso-Rasgado, T., Thompson, G. and Elfstrom, B., The design of functional (total care) products, Journal of Engineering Design, Vol. 15, No. 6 (2004), pp. 515-540.

Anderson, D., Agile Product Development for Mass Customization (1997), Chicago, IL, Irwin.

Arai, T. and Shimomura, Y., Proposal of Service CAD System -A Tool for Service Engineering-, Annals of the CIRP, Vol. 53, No. 1 (2004), pp. 397-400.

Aurich, J. C., Fuchs, C. and Wagenknecht, C., Life cycle oriented design of technical Product-Service Systems, Journal of Cleaner Production, Vol. 14, No. 17 (2006), pp. 1480-1494.

Baines, T. S., Bigdeli, A. Z., Bustinza, O. F. and Ridgway, K., Servitization: Revisiting the State-of-the-art and Research Priorities, International Journal of Operations \& Production Management, Vol. 37, No. 2 (2017), pp. 256-278.

Baldwin, C. Y. and Clark, K. B., Design Rules, Volume 1: The Power of Modularity (2000), Cambridge, MA, The MIT Press.

Becker, J., Beverungen, D. F. and Knackstedt, R., The challenge of conceptual modeling for product-service systems: status-quo and perspectives for reference models and modeling languages, Information Systems and e-Business Management, Vol. 8 (2010), pp. 33-66.

Berkovich, M., Krcmar, H. and Leimeister, J., Requirements Engineering for Product Service Systems - A State of the Art Analysis, Business \& Information Systems Engineering, Vol. 3, No. 6 (2011), pp. 369-380.

Boehm, M. and Thomas, O., Looking beyond the rim of one's teacup: A multidisciplinary literature review of ProductService Systems in Information Systems, Business Management, and Engineering \& Design, Journal of Cleaner Production, Vol. 51 (2013), pp. 245-260.

Brax, S. A., Bask, A., Hsuan, J. and Voss, C., Service modularity and architecture - an overview and research agenda, International Journal of Operations \& Production Management, Vol. 37, No. 6 (2017), pp. 686-702.

Broekhuis, M., van Offenbeek, M. and Eissens-van der Laan, M., What professionals consider when designing a modular service architecture, International Journal of Operations \& Production Management, Vol. 37, No. 6 (2017), pp. 748-770.

da Silveira, G., Borenstein, D. and Fogliatto, F. S., Mass customization: Literature review and research directions, International Journal of Production Economics, Vol. 72 (2001), pp. 1-13.

Durugbo, C., Tiwari, A. and Alcock, J. R., A review of information flow diagrammatic models for product-service systems, The International Journal of Advanced Manufacturing Technolgy, Vol. 52 (2011), pp. 1193-1208.

Fargnoli, M., Haber, N. and Sakao, T., PSS Modularization - A Customer Driven Integrated Approach, International Journal of Production Research (2018), DOI: 10.1080/00207543.2018.1481302.

Fogliatto, F. S. and da Silveira, G. J. C., Mass customization: a method for market segmentation and choice menu design, 
International Journal of Production Economics, Vol. 111 (2008), pp. 606-622.

Fogliatto, F. S., da Silveira, G. J. C. and Borenstein, D., The masscustomization decade: An updated review of the literature, International Journal of Production Economics, Vol. 138 (2012), pp. 14-25.

Fujita, K. and Yoshida, H. (2001). Product variety optimization: Simultaneous optimization of module combination and module attributes. ASME Design Engineering Technology Conferences, DETC20010 DAC-21058.

Geng, X. and Chu, X., A new importance-performance analysis approach for customer satisfaction evaluation supporting PSS design, Expert Systems with Applications, Vol. 39 (2012), pp. 1492-1502.

Geng, X., Chu, X., Xue, D. and Zhang, Z., An integrated approach for rating engineering characteristics' final importance in product-service system development, Computers \& Industrial Engineering, Vol. 59 (2010), pp. 585-594.

Hara, T., Arai, T. and Shimomura, Y., A CAD system for service innovation: integrated representation of function, service activity, and product behaviour, Journal of Engineering Design, Vol. 20, No. 4 (2009), pp. 367-388.

Hu, S. J., Ko, J., Weyand, L., ElMaraghy, H. A., Lien, T. K., Koren, Y., Bley, H., Chryssolouris, G., Nasr, N. and Shpitalni, M., Assembly system design and operations for product variety, CIRP Annals - Manufacturing Technology, Vol. 60, No. 2 (2011), pp. 715-733.

Hubka, V. and Eder, W. E., Design Science (1996), London, Springer.

Jiao, J., Ma, Q. and Tseng, M., Towards high value-added products and services: mass customization and beyond, The International Journal of Technological Innovation, Entrepreneurship and Technology Management, Vol. 23 (2003), pp. 809-821.

Jiao, J. R., Simpson, T. W. and Siddique, Z., Product family design and platform-based product development: a state-ofthe-art review, Journal of Intelligent Manufacturing, Vol. 18 (2007), pp. 5-29.

Komoto, H. and Tomiyama, T., Integration of a service CAD and a life cycle simulator, CIRP Annals - Manufacturing Technology, Vol. 57, No. 1 (2008), pp. 9-12.

Kowalkowski, C., Windahl, C., Kindström, D. and Gebauer, H., What service transition? Rethinking established assumptions about manufacturers' serviceled growth strategies, Industrial Marketing Management, Vol. 45 (2015), pp. 59-69.

Kuo, T. C., Mass customization and personalization software development: a case study eco-design product service system, Journal of Intelligent Manufacturing, Vol. 24, No. 5 (2013), pp. 1019-1031.

McKay, A. and Kundu, S., A representation scheme for digital product service system definitions, Advanced Engineering Informatics, Vol. 28 (2014), pp. 479-498.

Meier, H., Roy, R. and Seliger, G., Industrial Product-Service Systems - IPS², CIRP Annals - Manufacturing Technology, Vol. 59, No. 2 (2010), pp. 607-627.

Ming, D. and Liyue, S., Modeling a Configuration System of Product-Service System Based on Ontology Under Mass Customization, Advanced Science Letters, Vol. 4 (2011), pp. 2256-2261.

Moon, S. K., Shu, J., Simpson, T. W. and Kumara, S. R. T., A module-based service model for mass customization: service family design, IIE Transactions, Vol. 43, No. 3 (2011), pp. 153-163.

Moon, S. K., Simpson, T. W., Shu, J. and R. T. Kumara, S., Service representation for capturing and reusing design knowledge in product and service families using object-oriented concepts and an ontology, Journal of Engineering Design, Vol. 20, No. 4 (2009), pp. 413 - 431.

Morelli, N., Product-service systems, a perspective shift for designers: A case study: the design of a telecentre, Design Studies, Vol. 24, No. 1 (2003), pp. 73-99.

Newcomb, P. J., Bras, B. and Rosen, D. W. (1996). Implications of modularity on product design for the life cycle. ASME Design Engineering Technical Conferences, Irvine, CA, 96-DETC/DTM-1516.

Pine, J., Mass Customization: the New Frontier in Business Competition (1993), Boston, MA, Harvard Business School Press.

Pine, J., Mass Customization (1997), Harvard Business School Press.

Qu, M., Yu, S., Chen, D., Chu, J. and Tian, B., State-of-the-art of design, evaluation, and operation methodologies in product service systems, Computers in Industry, Vol. 77 (2016), pp. 1-14.

Raja, J. Z., Frandsen, T. and Mouritsen, J., Exploring the managerial dilemmas encountered by advanced analytical equipment providers in developing service-led growth strategies, International Journal of Production Economics, Vol. 192 (2017), pp. 120-132.

Robertson, D. and Ulrich, K., Planning for product platforms, Sloan Management Review, Vol. 39, No. 4 (1998), pp. 19 
31.

Sakao, T., Napolitano, N., Tronci, M., Sundin, E. and Lindahl, M., How are product-service combined offers provided in Germany and Italy? Analysis with company sizes and countries, Journal of Systems Science and Systems Engineering, Vol. 17, No. 3 (2008), pp. 367-381.

Sakao, T. and Shimomura, Y., Service Engineering: A Novel Engineering Discipline for Producers to Increase Value Combining Service and Product, Journal of Cleaner Production, Vol. 15, No. 6 (2007), pp. 590-604.

Sakao, T., Shimomura, Y., Comstock, M. and Sundin, E., A Method of Value Customization, Journal for Theory and Application in Mechanical Engineering, Vol. 49, No. 2 (2007), pp. 99 - 108.

Sakao, T., Shimomura, Y., Sundin, E. and Comstock, M., Modeling Design Objects in CAD System for Service/Product Engineering, Computer-Aided Design, Vol. 41, No. 3 (2009), pp. 197-213.

Sakao, T., Song, W. and Matschewsky, J., Creating service modules for customising product/service systems by extending DSM, CIRP Annals - Manufacturing Technology, Vol. 66, No. 1 (2017), pp. 21-24.

Schilling, M. A., Toward a general modular systems theory and its application to interfirm product modularity, Academy of Management Review, Vol. 25, No. 2 (2000), pp. 312-334.

Shimomura, Y. and Hara, T., Method for Supporting Conflict Resolution for Efficient PSS Development, CIRP Annals Manufacturing Technology, Vol. 59, No. 1 (2010), pp. 191-194.

Shostack, G. L., How to Design a Service, European Journal of Marketing, Vol. 16, No. 1 (1982), pp. 49-63.

Simpson, T. W., Product platform design and customization: Status and promise, Artificial Intelligence for Engineering Design, Analysis and Manufacturing, Vol. 18 (2004), pp. 3-20.

Song, W., Ming, X., Han, Y., Xu, Z. and Wu, Z., An integrative framework for innovation management of productservice system, International Journal of Production Research, Vol. 53, No. 8 (2015), pp. 2252-2268.

Song, W. and Sakao, T., A customization-oriented framework for design of sustainable product/service system, Journal of Cleaner Production, Vol. 140, No. 3 (2017), pp. 1672-1685.

Tischner, U., Verkuijl, M. and Tukker, A. (2002). First Draft PSS Review. Cologne, Econcept.

Tukker, A., Eight Types of Product-Service System: Eight Ways to Sustainability? Experiences from Suspronet, Business Strategy and the Environment, Vol. 13 (2004), pp. 246 - 260.

Tukker, A., Product services for a resource-efficient and circular economy - a review, Journal of Cleaner Production, Vol. 97 (2015), pp. 76-91.

Tukker, A. and Tischner, U., Product-services as a research field: past, present and future. Reflections from a decade of research, Journal of Cleaner Production, Vol. 14, No. 17 (2006), pp. 1552-1556.

Ulrich, K. T., The role of product architecture in the manufacturing firm, Research Policy, Vol. 24 (1995), pp. 419-440.

Ulrich, K. T. and Eppinger, S. D., Product Design And Development (2000), Irwin McGraw-Hill.

Umeda, Y., Takata, S., Kimura, F., Tomiyama, T., Sutherland, J. W., Kara, S., Herrmann, C. and Duflou, J. R., Toward integrated product and process life cycle planning - An environmental perspective, CIRP Annals - Manufacturing Technology, Vol. 61, No. 2 (2012), pp. 681-702.

Vandermerwe, S., Jumping into the customer's activity cycle: A new role for customer services in the 1990s, Columbia Journal of World Business, Vol. 28, No. 2 (1993), pp. 46-65.

Vasantha, G. V. A., Roy, R., Lelah, A. and Brissaud, D., A review of product-service systems design methodologies, Journal of Engineering Design, Vol. 23, No. 9 (2012), pp. 635-659.

Visintin, F., Providing integrated solutions in the professional printing industry: The case of Océ, Computers in Industry, Vol. 63, No. 4 (2012), pp. 379-388.

Webster, J. and Watson, R. T., Analyzing the Past to Prepare for the Future: Wrting a Literature Review, MIS Quarterly, Vol. 26, No. 2 (2002), pp. 11-19. 